\title{
Grazing Animal Preferences for Cultivated Forages in Canada
}

\author{
R.H. GESSHE AND P.D. WALTON
}

\begin{abstract}
Ten perennial forage species and one forage mixture were evaluated for yield and animal preference at three growth stages. The most preferred but lowest yielding grass was Russian wild rye. Intermediate wheatgrass yielded most but was less preferred. Bromegrass gave high yields and was a preferred species. For the legumes, birdsfoot trefoil had the highest preference rating and also gave some high yields. Alfalfa was a productive, preferred species. The advantages, in terms of both animal preference and production, of a mixed forage stand over pastures containing a single species were demonstrated. Plant moisture, crude protein, digestibility, and crude fibre all influenced preference at certain times of the growing season.
\end{abstract}

Animal nutrition plays an important role in grazing management. The animal makes a marked contribution to this management process by selecting plant species and plant parts from a mixed sward. Consequently, it determines its own nutritional level in terms of both quality and quantity. Animals ingest greater quantities of preferred species and this increased intake affects the animal's weight gain (Cowlishaw and Alder 1960, Tribe 1952). Also, the physical and chemical properties of a forage influence selective grazing behaviour of animals (Hardison et al. 1954, Meyer et al. 1957, Tribe 1952) so that the quality of the material consumed is also determined by animal selection.

Much research in animal grazing preference has been conducted on native rangeland. Information regarding animal preference for cultivated forage species in western Canada is limited. Thus, this study undertook to determine the preferences of steers offered an assortment of cultivated forages. The forage quality characteristics of the material for which the animals showed a preference was also studied.

\footnotetext{
The authors are, respectively, instructor in the Plant Science Department at Old's College and professor and chairman of the Department of Plant Science, University of Alberta. This work was made possible by grants from the Alberta Cattle Commission and the Alberta Agricultural Research Trust.

Manuscript received May 8, 1979.
}

\section{Materials and Methods}

The study was conducted at the University of Alberta Ranch at Kinsella, situated in the thin black soil zone in east-central Alberta. The soil was a glacial loam of the Viking moraine (Wyatt et al. 1944). Topographically, the area is rolling to hilly with sloughs occurring in the depressions. Mean annual precipitation is $40.6 \mathrm{~cm}$ with the maximum precipitation occurring between July 1st and July 15 th (Wonders 1969). Ten forages and one forage mixture $(2.24 \mathrm{~kg} / \mathrm{ha}$ alfalfa, $4.48 \mathrm{~kg} / \mathrm{ha}$ creeping red fescue, $6.72 \mathrm{~kg} / \mathrm{ha}$ bromegrass) were sown on May 31 and June 2, 1972, in strips $3.5 \mathrm{~m}$ wide and $45.7 \mathrm{~m}$ long at the rates and row spacings listed in Table 1. By the second year, forage establishment was good. The study area was separated into three pastures each containing four replications of each species and the mixture. A 15.2-m length from each $3.5-\mathrm{m}$ strip was fenced to form exclosures. In 1973, these three pastures were grazed when the plants were in the vegetative stage (May 31 to June 17), at heading or flowering (June 21 to July 10 ) and at or after seed set (July 11 to July 31 ). After each grazing period, one-half meter samples were clipped from each plot in both the grazed and exclosed area. Samples were divided into leaves and stems, dried at $65^{\circ} \mathrm{C}$, and weighed.

Production was the total dry weight from each clipped species in the exclosed area. Utilization was the difference between the total forage clipped from the grazed area and that corresponding from the exclosure. The preference rating was calculated by the method used by Van Dyne and Heady (1965) and Rosiere et al. (1975). Values greater than 1.0 indicated preference, values less than 1.0 indicated avoidance. In addition to evaluating dry matter production (and, consequently, percent moisture) for leaves and stem, the clipped samples were used to determine the proportion of leaves by weight as well as percent crude protein, acid detergent fibre, and acid-pepsin dry matter disappearance. Crude protein was determined with a Colman nitrogen analyzer (Stavant et al. 1963). The Van Soest method (1963) was used for acid detergent fibre evalua- 
Table 1. Seeding rates, production, utilization, and relative preference rating for ten forages and a forage mixture for three grazing periods. ${ }^{1}$

\begin{tabular}{|c|c|c|c|c|c|c|c|c|c|c|}
\hline \multirow[b]{2}{*}{ Species } & \multirow[b]{2}{*}{$\begin{array}{l}\text { Seeding } \\
\text { rate } \\
(\mathrm{kg} / \mathrm{ha})\end{array}$} & \multicolumn{3}{|c|}{ Grazing Period 1} & \multicolumn{3}{|c|}{ Grazing Period 2} & \multicolumn{3}{|c|}{ Grazing Period 3} \\
\hline & & $\begin{array}{l}\text { Produc- } \\
\text { tion } \\
\text { (kg/ha) }\end{array}$ & $\begin{array}{l}\text { Utiliz- } \\
\text { ation } \\
\text { (kg/ha) }\end{array}$ & $\begin{array}{c}\text { Pre- } \\
\text { ference } \\
\text { rating }\end{array}$ & $\begin{array}{l}\text { Produc- } \\
\text { tion } \\
\text { (kg/ha) }\end{array}$ & $\begin{array}{l}\text { Utiliz- } \\
\text { ation } \\
\text { (kg/ha) }\end{array}$ & $\begin{array}{c}\text { Pre } \\
\text { ference } \\
\text { rating }\end{array}$ & $\begin{array}{l}\text { Produc- } \\
\text { tion } \\
(\mathrm{kg} / \mathrm{ha})\end{array}$ & $\begin{array}{l}\text { Utiliz- } \\
\text { ation } \\
(\mathrm{kg} / \mathrm{ha})\end{array}$ & $\begin{array}{c}\text { Pre- } \\
\text { ference } \\
\text { rating }\end{array}$ \\
\hline Bromegrass & 6.7 & 2320 & 1320 & 1.2 & 5700 & 2840 & 1.0 & 6140 & 2800 & 1.2 \\
\hline Creeping red fescue & 9.0 & 2900 & 1400 & 1.1 & 5130 & 1510 & 0.6 & 5190 & 0 & 0.0 \\
\hline Crested wheatgrass & 11.2 & 1550 & 560 & 0.8 & 3140 & 340 & 0.2 & 4170 & 0 & 0.0 \\
\hline Intermediate wheatgrass & 9.0 & 2870 & 1560 & 1.2 & 6160 & 690 & 0.2 & 5760 & 42 & 0.0 \\
\hline Redtop & 10.1 & 1260 & 530 & 0.9 & 4080 & 2060 & 1.1 & 6330 & 3500 & 1.5 \\
\hline Russian wild ryegrass & 5.6 & 650 & 350 & 1.2 & 790 & 720 & 1.9 & 1580 & 1000 & 1.7 \\
\hline Alfalfa & 6.7 & 1700 & 980 & 1.3 & 4370 & 3260 & 1.5 & 7680 & 3730 & 1.3 \\
\hline Birdsfoot trefoil & 12.3 & 830 & 350 & 0.9 & 5270 & 4630 & 1.8 & 4360 & 3060 & 1.9 \\
\hline Sainfoin & 20.2 & 1640 & 380 & 0.5 & 3330 & 1060 & 0.7 & 4170 & 1200 & 0.8 \\
\hline White clover & 7.8 & 1020 & 20 & 0.0 & 3680 & 2220 & 1.2 & 6250 & 3770 & 1.6 \\
\hline Forage mixture ${ }^{2}$ & 13.4 & 2320 & 1320 & 1.2 & 5780 & 3640 & 1.3 & 8300 & 4230 & 1.4 \\
\hline Mean & $\ldots$. & 1730 & 800 & & 4310 & 2090 & & 5450 & 2040 & \\
\hline at $5 \%$ Level & - & 835 & 939 & & 2120 & 2250 & & 3380 & 2760 & \\
\hline $1 \%$ Level & - & 1125 & - & 2850 & 3040 & & 4550 & 3730 & & \\
\hline
\end{tabular}

${ }^{1}$ Row spacing was $17.8 \mathrm{~cm}$ except for Russian wild ryegrass, which was $35.6 \mathrm{~cm}$.

${ }^{2}$ Alfalfa $(2.24 \mathrm{~kg} / \mathrm{ha})$, creeping red fescue $(4.48 \mathrm{~kg} / \mathrm{ha})$ and bromegrass $(6.72 \mathrm{~kg} / \mathrm{ha})$.

tions. The acid-pepsin determination was that used by Donefer et al. (1966), Koundall et al. (1970) and Sleper et al. (1973).

The various chemical and physical forage characteristics studied were compared with the animal preference rating by using stepwise multiple regression. This method introduced variables into the regression equation according to the proportion of variation of the dependent variable accounted for. The regression analysis was considered complete when the introduction of a new independent variable resulted in a change of less than one per cent of the variance of the dependent variable. Simple correlation coefficients were calculated between all variables studied.

\section{Results and Discussion}

\section{Animal Preference}

During the first grazing period, plants were in vegetative stage and differences in preference were small, with the exception that white clover and sainfoin were rejected. Some preference was shown for bromegrass, intermediate wheatgrass, Russian wild ryegrass, alfalfa and the forage mixture. With the exception of Russian wild ryegrass, these species were also high yielding (Table 1). Overall, grasses were preferred (Preference rating $=1.06$ ) over legumes $(0.78)$. By the second grazing period this situation was reversed. The grasses had a mean preference rating of 0.6 , while that for legumes was 1.04 (Table 1). Russian wild ryegrass was the most highly utilized species, closely followed by birdsfoot trefoil which gave a high yield. Alfalfa was another preferred species which was also highly productive. The animals avoided crested wheatgrass, intermediate wheatgrass and sainfoin during this grazing period. This rejection of intermediate wheatgrass is unfortunate in view of the high yield obtained $(6,160 \mathrm{~kg}$ per ha). During the third grazing period (Table 1) three grasses (creeping red fescue, crested wheatgrass and intermediate wheatgrass) were rejected entirely. The animals avoided only one legume (sainfoin). The forage mixture yielded the highest $(8,300 \mathrm{~kg}$ per ha) and it was well

Table 2. Protein, acid detergent fibre, digestiblity (acid pepsin dry matter disappearance) moisture content and per cent leaf for ten forage species for three grazing periods1.

\begin{tabular}{|c|c|c|c|c|c|c|c|c|c|c|c|c|c|c|c|c|c|c|c|c|c|c|c|c|}
\hline \multirow[b]{3}{*}{ Species } & \multicolumn{6}{|c|}{ Crude protein (\%) } & \multicolumn{6}{|c|}{$\begin{array}{c}\text { (Crude fibre) } \\
\text { Acid detergent fibre (\%) }\end{array}$} & \multicolumn{6}{|c|}{$\begin{array}{c}\text { (Digestibility) } \\
\text { Acid pepsin dry matter dis- } \\
\text { appearance }(\%)\end{array}$} & \multirow{2}{*}{\multicolumn{3}{|c|}{$\begin{array}{c}\begin{array}{c}\text { Moisture } \\
\text { content }\end{array} \\
\text { Grazing Period } \\
\end{array}$}} & \multirow{2}{*}{\multicolumn{3}{|c|}{$\begin{array}{l}\text { Leaf dry weight } \\
\text { as \% of total } \\
\text { plant dry weight } \\
\text { Grazing Period }\end{array}$}} \\
\hline & \multicolumn{3}{|c|}{$\begin{array}{c}\text { Leaf } \\
\text { Grazing Period }\end{array}$} & \multicolumn{3}{|c|}{$\begin{array}{c}\text { Stem } \\
\text { Grazing Period }\end{array}$} & \multicolumn{3}{|c|}{$\begin{array}{c}\text { Leaf } \\
\text { Grazing Period }\end{array}$} & \multicolumn{3}{|c|}{$\begin{array}{c}\text { Stem } \\
\text { Grazing Period } \\
\end{array}$} & \multicolumn{3}{|c|}{$\begin{array}{c}\text { Leaf } \\
\text { Grazing Period }\end{array}$} & \multicolumn{3}{|c|}{$\begin{array}{c}\text { Stem } \\
\text { Grazing Period } \\
\end{array}$} & & & & & & \\
\hline & 1 & 2 & 3 & 1 & 2 & 3 & 1 & 2 & 3 & 1 & 2 & 3 & 1 & 2 & 3 & 1 & 2 & 3 & $\overline{1}$ & 2 & 3 & 1 & 2 & 3 \\
\hline $\begin{array}{l}\text { Bromegrass } \\
\text { Creeping red fescue } \\
\text { Crested wheatgrass } \\
\text { Intermediate wheatgrass } \\
\text { Red top } \\
\text { Russian wild ryegrass }\end{array}$ & $\begin{array}{l}16.9 \\
17.6 \\
24.2 \\
18.6 \\
21.6 \\
23.0\end{array}$ & $\begin{array}{l}18.9 \\
11.7 \\
19.1 \\
15.3 \\
16.3 \\
21.8\end{array}$ & $\begin{array}{r}15.0 \\
8.6 \\
17.8 \\
15.9 \\
16.1 \\
16.5\end{array}$ & $\begin{array}{l}10.9 \\
14.6 \\
13.5 \\
11.2 \\
11.1 \\
14.9\end{array}$ & $\begin{array}{r}8.5 \\
8.5 \\
10.7 \\
8.3 \\
9.9 \\
12.1\end{array}$ & $\begin{array}{r}7.2 \\
5.5 \\
10.2 \\
7.8 \\
7.4 \\
8.3\end{array}$ & $\begin{array}{l}34.3 \\
34.0 \\
31.0 \\
34.8 \\
38.2 \\
31.5\end{array}$ & $\begin{array}{l}33.8 \\
34.6 \\
33.0 \\
34.0 \\
32.4 \\
31.0\end{array}$ & $\begin{array}{l}33.4 \\
32.5 \\
34.0 \\
33.7 \\
36.3 \\
33.1\end{array}$ & $\begin{array}{l}37.8 \\
36.0 \\
33.6 \\
32.1 \\
29.4 \\
40.3\end{array}$ & $\begin{array}{l}44.3 \\
44.5 \\
39.7 \\
44.6 \\
38.9 \\
42.2\end{array}$ & $\begin{array}{l}39.6 \\
45.6 \\
39.8 \\
41.5 \\
39.4 \\
45.2\end{array}$ & $\begin{array}{l}34.9 \\
31.4 \\
40.5 \\
32.7 \\
43.1 \\
37.7\end{array}$ & $\begin{array}{l}35.0 \\
30.7 \\
35.7 \\
28.9 \\
32.2 \\
35.6\end{array}$ & $\begin{array}{l}35.0 \\
35.0 \\
31.2 \\
28.4 \\
28.2 \\
30.9\end{array}$ & $\begin{array}{l}27.0 \\
26.1 \\
34.1 \\
35.0 \\
38.2 \\
23.5\end{array}$ & $\begin{array}{l}23.5 \\
19.9 \\
28.0 \\
17.6 \\
25.0 \\
23.0\end{array}$ & $\begin{array}{l}29.0 \\
19.1 \\
25.9 \\
24.1 \\
27.9 \\
17.2\end{array}$ & $\begin{array}{l}76 \\
66 \\
71 \\
69 \\
73 \\
71\end{array}$ & $\begin{array}{l}67 \\
68 \\
62 \\
69 \\
75 \\
69\end{array}$ & $\begin{array}{l}54 \\
57 \\
54 \\
55 \\
62 \\
64\end{array}$ & $\begin{array}{l}43 \\
37 \\
35 \\
55 \\
47 \\
82\end{array}$ & $\begin{array}{l}44 \\
38 \\
20 \\
35 \\
55 \\
89\end{array}$ & $\begin{array}{l}24 \\
50 \\
25 \\
26 \\
36 \\
83\end{array}$ \\
\hline $\begin{array}{l}\text { Alfalfa } \\
\text { Birdsfood trefoil } \\
\text { Sainfoin }\end{array}$ & $\begin{array}{l}26.5 \\
28.0 \\
26.0\end{array}$ & $\begin{array}{l}25.4 \\
19.6 \\
26.5\end{array}$ & $\begin{array}{l}28.2 \\
19.8 \\
22.8\end{array}$ & $\begin{array}{l}13.9 \\
14.5 \\
11.4\end{array}$ & $\begin{array}{l}10.5 \\
10.9 \\
13.7\end{array}$ & $\begin{array}{r}11.9 \\
9.2 \\
9.8\end{array}$ & $\begin{array}{l}22.6 \\
23.2 \\
34.6\end{array}$ & $\begin{array}{l}19.7 \\
26.5 \\
22.2\end{array}$ & $\begin{array}{l}22.2 \\
42.0 \\
26.7\end{array}$ & $\begin{array}{l}42.4 \\
50.1 \\
46.9\end{array}$ & $\begin{array}{l}49.7 \\
50.1 \\
45.9\end{array}$ & $\begin{array}{l}47.6 \\
49.4 \\
47.6\end{array}$ & $\begin{array}{l}58.6 \\
55.1 \\
41.0\end{array}$ & $\begin{array}{l}54.6 \\
47.0 \\
47.2\end{array}$ & $\begin{array}{l}52.7 \\
42.8 \\
42.8\end{array}$ & $\begin{array}{l}37.1 \\
36.5 \\
30.6\end{array}$ & $\begin{array}{l}30.2 \\
28.1 \\
30.2\end{array}$ & $\begin{array}{l}30.6 \\
27.7 \\
26.9\end{array}$ & $\begin{array}{l}78 \\
81 \\
82\end{array}$ & $\begin{array}{l}73 \\
74 \\
75\end{array}$ & $\begin{array}{l}66 \\
71 \\
64\end{array}$ & $\begin{array}{l}55 \\
62 \\
53\end{array}$ & $\begin{array}{l}51 \\
45 \\
47\end{array}$ & $\begin{array}{l}44 \\
42 \\
40\end{array}$ \\
\hline White clover & 20.8 & 19.6 & 18.4 & -2 & - & - & 27.9 & 33.7 & 36.0 & - & - & - & 47.1 & 41.8 & 38.8 & - & - & - & 79 & 78 & 69 & - & - & - \\
\hline $\begin{array}{l}\operatorname{LSD}(0.05) \\
\operatorname{LSD}(0.01)\end{array}$ & $\begin{array}{l}1.1 \\
1.6\end{array}$ & $\begin{array}{l}1.6 \\
2.3\end{array}$ & $\begin{array}{l}1.0 \\
1.4\end{array}$ & $\begin{array}{l}0.9 \\
1.3\end{array}$ & $\begin{array}{l}0.9 \\
1.3\end{array}$ & $\begin{array}{l}0.9 \\
1.3\end{array}$ & $\begin{array}{l}0.4 \\
0.6\end{array}$ & $\begin{array}{l}0.6 \\
0.8\end{array}$ & $\begin{array}{l}0.1 \\
0.2\end{array}$ & $\begin{array}{l}0.1 \\
0.2\end{array}$ & $\begin{array}{l}0.5 \\
0.7\end{array}$ & $\begin{array}{l}0.3 \\
0.4\end{array}$ & $\begin{array}{l}0.7 \\
1.0\end{array}$ & $\begin{array}{l}1.2 \\
1.7\end{array}$ & $\begin{array}{l}0.8 \\
1.2\end{array}$ & $\begin{array}{l}0.8 \\
1.1\end{array}$ & $\begin{array}{l}0.6 \\
0.9\end{array}$ & $\begin{array}{l}1.3 \\
1.9\end{array}$ & $\begin{array}{l}3 \\
9\end{array}$ & & & & & \\
\hline
\end{tabular}

${ }^{1}$ Row spacing was $17.8 \mathrm{~cm}$ apart for all species except Russian wild ryegrass, which was $35.6 \mathrm{~cm}$.

${ }^{2}$ White clover stems not analyzed 


\section{liked by the animals.}

Considering all grazing periods, steers preferred Russian wild ryegrass but it had low yields because of wide row spacing and slow establishment. Once established, it has been reported to out-yield bromegrass and crested wheatgrass in the brown soil zone (Lawrence and Heinrichs 1966). Russian wild ryegrass was probably preferred because it had the highest proportion of leaves and highest moisture content of all the grass species (Table 2). Bromegrass yielded slightly less than intermediate wheatgrass but was most utilized of all grasses throughout the trial. Animal preference for red top increased as the season progressed. This species matures late, retaining many leaves and having relatively high moisture toward the end of the season. For intermediate and crested wheatgrasses, the decline in preference from the first of the third grazing period was associated with a decline in the proportion of leaves and leaf moisture and an increase in crude fiber (Table 2). Intermediate wheatgrass was the highest producing species. It grew rapidly, matured late and was relatively low in protein. Lawrence et al. (1971) recommended intermediate wheatgrass over bromegrass or reed canarygrass (Phalaris arundinacea L.) for irrigated conditions because of its high dry matter yield.

With the exception of the first grazing period, birdsfoot trefoil was the most preferred legume, giving high yields and outproducing alfalfa during the second grazing period. The animals did not readily graze this species when first turned into a pasture, but subsequent utilization was high. Alfalfa was a productive, well-utilized species with a high proportion of leaves. Sainfoin was avoided throughout the trial. It was relatively high yielding during the first grazing period but was the lowest yielding legume in the second and third periods. Hanna et al. (1972) reported sainfoin yields to be $85 \%$ of alfalfa. The animals selected only the leaves of this forage, leaving stems untouched. White clover yielded little in the first grazing period but yields increased later in the season. Cooper et al. (1971) in Montana also reported poor forage yields for white clover.

Animals preferred the forage mixture during all grazing periods, suggesting that grazing animals were attracted to a heterogenous plant community (Jones 1952). The high production from the mixture may be attributed to the effect which the nitrogen fixing legume had on grass yields. The variation in individual animal preference gave the forage mixtures on advantage when compared to pure stands because each animal had a choice of forage, allowing individuals to adjust their own diets. The forages tested in this trial are all commonly seeded into Alberta pastures. Any of them would be readily utilized by cattle if no alternatives were offered. Minor variations in utilization, such as were obtained during the first grazing period, were of little practical significance because they probably would not affect animal intake. Also, variations in individual a nimal grazing behaviour nullified $(P>0.05)$ the importance of small over all differences in animal preference.

\section{Forage Quality Characters Associated with Animal Preference}

For each grazing period (vegetative, flowering, and seed set) a multiple regression equation was developed to evalute the effect of various forage quality factors on the preference rating $(Y)$. The prediction equation developed for the first grazing period was not significant. The high quality (Table 2 ) of all species at this time discouraged selective grazing patterns based on forage quality. A significant $(P<0.01)$ multiple regression equation was developed for the second grazing period. Simple correlation coefficients indicated that the percent leaves, stems, crude fibre, and stem acidpepsin dry matter disappearance had a positive influence on the preference rating during this period, while both leaf and stem protein decreased animal preference. The prediction formula was $\left(R^{2}=0.94\right)$.

$$
Y=-4.21+0.04 x_{2}+0.07 x_{8}+0.12 x_{9}-0.07 x_{4}-0.12 x_{7}
$$

where $x_{2}$ was percent leaves by weight, $x_{8}$ percent crude fibre in the stem, $x_{9}$ acid-pepsin dry matter disappearance in the stem, $x_{4}$ percent leaf crude protein, and $x_{7}$ percent stem crude protein. The mature forage data from the third grazing period showed $(P<0.01)$ that moisture $\left(x_{1}\right)$ was the major positive influence on the preference rating. The prediction equation $\left(R^{2}=0.77\right)$ was:

$$
\begin{gathered}
Y=-2.42+0.16 x_{1}-0.15 x_{8}+0.01 x_{2} \\
\text { where } x_{8}-2.42+0.16 x_{1}-0.15 x_{8}+0.01 x_{2}
\end{gathered}
$$

Coleman and Barth (1973), Fontenot and Blaser (1965), Hardison et al. (1954), Weir and Torell (1959), and Rama Rao et al. (1973) all showed that grazing animals tend to select diets high in crude protein, easily digestible, and low in crude fibre when offered a variety of forage. Other workers (Crampton 1957, Dubbs 1966, Meyer et al. 1957, Milford and Minson 1966, Tribe 1952, Van Soest 1964) reported poor correlations between preference or intake and the nutritional value of forages. Crampton (1957) indicated that as long as the animal's basic nutritional needs were satisfied, little selection was likely to occur. In other studies, a close relationship existed between preference or intake and nutritive forage value (Blaxter et al. 1961, Blaser et al. 1960, Cook 1959, Plice 1952). This study indicated that the various quality components do influence animal preference. The multiple regression relationships between crude protein, digestibility, and crude fibre associated these characters with animal preference. Moisture content of forage is seldom mentioned as a factor in forage preference. Here, moisture content significantly $(P<0.01)$ affected preference in the third grazing period. Hilton and Bailey (1972), also working on the University of Alberta Ranch, reported the importance of moisture content to animal preference for native forage species.

\section{Literature Cited}

Blaser, R.E., R.C. Hames, H.T. Bryant, W.A. Hardison, J.P. Fontenot, and $R$.W. Engel. 1960. The effect of selective grazing on animal output. Proc. 8th Int. Grassland Cong., Reading 601-606.

Blaxter, K.L., F.W. Wainman, and R.S. Wilson. 1961. The regulation of food intake by sheep. Animal Prod. 3:51-61.

Cowlishaw, S.J., and F.E. Alder. 1960. The grazing preferences of cattle and sheep. J. Agric. Sci. 54:257-265.

Crampton, E.W. 1957. Inter-relations between digestible nutrient and energy content voluntary intake and the overall feeding value of forages. J. Animal Sci. 16:546-552.

Donefer, E., E.W. Crampton, and L.E. Lloyd. 1966. The prediction of digestible energy intake potential (NVI) for forages using a simple in vitro technique. Proc. 10th Int. Grassland Cong. Helsinki 442-445.

Dubbs, A.L. 1966. Yield, crude protein and palatability of dryland grasses in Central Montana. Montana Agr. Exp. Sta. Bull. 604.

Hanna, M.R., D.A. Cooke, S. Smoliak, and B.P. Goplen. 1972. Sainfoin for Western Canada. Dep. Agr. Pub. No. 1470.

Hardison, W.A., J.T. Reid, C.M. Martin, and P.G. Woofolk. 1954. Degree of herbage selection by grazing cattle. J. Dairy Sci. 37:89-102.

Hilton, J.E., and A.W. Bailey. 1972. Cattle use of a sprayed aspen parkland range. J. Range Manage. 25:257-260.

Jones, L.I. 1952. Measurement of palatability. Proc. 6th Int. Grassland Cong. Pennsylvania 1348-1353.

Kendall, W.A., J.R. Todd, and W.C. Templeton, Jr. 1970. Simplification of dry matter disappearance technique to estimate forage quality. Crop. Sci. 10:47-48.

Lawrence, T., and D.H. Heinrichs. 1966. Russian wild ryegrass for Western Canada. Canada Dep. of Agr. Pub. 991.

Lawrence, T., F.G. Warder, and R. Ashford. 1971. Effect of stage and height of cutting on crude protein content and crude protein yield of intermediate wheatgrass, bromegrass and reed canary grass. Can J. Plant Sci. $51: 41-48$

Meyer, J.H., G.P. Lofgreen, and J.L. Hull. 1957. Selective grazing by sheep and cattle. J. Animal Sci. 16:766-772.

Milford, R., and J.J. Minson. 1966. Intake of tropical pasture species. Proc. 9th Int. Grassland Cong. Sao Paulo 815-822.

Plice, M.J. 1952. Sugar versus the intuitive choice of foods by livestock. J. Range Manage. 5:69-75.

Rosiere, R.E., R.F. Beck, and J.D. Wallace. 1975. Cattle diets on semidesert grassland-Botanical composition. J. Range Manage. 28:89-93.

Sleper, D.A., P.N. Drolsom, and N.A. Jorgensen. 1973. Breeding for improved dry matter digestibility in smooth bromegrass. Crop Sci. 13: 556-558. 
Stewart, B.A., L.K. Porter, and F.E. Clerk. 1963. The reliability of a micro-dumas procedure for determining total nitrogen in soil. Soil Sci. Soc. Proc. 377-380.

Tribe, D.E. 1952. The relationship of palatability to nutritive value and its importance in the utilization of herbage by grazing animals. Proc. 6th Int. Grassland Cong. 1265-1270.

Van Dyne, G.M., and H.F. Heady. 1965. Botanical composition of cattle and sheep diets on a nature annual range. Hilgardia 36:465-490.

Van Soest, P.J. 1963. The use of detergents in analysis of fibrous feeds. J.
Ass. Official Agr. Chem. 46:829-835.

Van Soest, P.J. 1964. Symposium on nutrition, forages and pastures: New chemical procedures for evaluating forage. J. Animal Sci. 23:838-845

Wonders, W.C. 1969. Atlas of Alberta. Univ. Alberta Press and Univ. Toronto Press.

Wyatt, F.A., D. Newton, W.E. Bowser and W. Odynsky. 1944. Soil survey of Wainwright and Vermilion sheets. Bulletin No. 42 Univ. Alberta Press. 